\title{
PROLIFERACIJA OROŽJA ZA MNOŽIČNO UNIČEVANJE - JRKB/E: NOVODOBNI IZZIV VARNOSTNIM SILAM V BOJU PROTI TERORIZMU1
}

\author{
PROLIFERATION OF CBRN/E WEAPONS: \\ A NEW CHALLENGE FOR SECURITY FORCES \\ IN COUNTER-TERRORISM
}

Povzetek Mednarodna javnost se srečuje s tretjo generacijo teroristov. Globalni džihad (sveta vojna) je spremenil svojo različico delovanja, saj posamezniki ali skupine delujejo tako, da sledijo voditeljevi nameri brez dejanskih navodil oziroma neposredne povezanosti s centralnim vodstvom. Glavno komunikacijsko orodje novodobnih teroristov je postal internet, hkrati pa je za tretjo generacijo teroristov značilna spremenjena vloga religije in ideologije. Dela islamskega učenjaka Ibn Taymija iz 13. stoletja, ki so obravnavala dolžnosti džihada, so se umaknila iz ospredja in niso več temeljna ideološka baza za globalno delovanje džihadistov 21. stoletja. Nova generacija teroristov prevzema svojo indoktrinacijo oziroma religiozno ideologijo od novodobnih islamskih radikalnih ideologov, objavljeno na internetu. Vodilna taktika uresničevanja nove ideologije in novih smernic džihada so serijska obglavljanja, posneta in predvajana na internetu in TV. Svojo taktiko pa džihad dopolnjuje z množičnimi izobčenji (takfir) članov terorističnih skupin, s čimer opravičuje umore muslimanov in do skrajnosti povečuje prag strpnosti do najhujših oblik nasilja med fanatičnimi ekstremisti. Ugrabitve, javna predvajanja mučenj in usmrtitev talcev ter izsiljevanja za visoke odkupnine postajajo eden pomembnejših virov financiranja džihada. Spremenjena taktika in nova ciljna interesna območja postajajo prednostna, vzporedno pa se dinamično spreminjata strategija in taktika globalnega boja proti terorizmu. Asimetrija ni več značilen vzorec oziroma termin, ki bi zadostno opisal in definiral nove različice delovanja džihada. Internetno organiziran informacijski kaos ustvarja in problematizira inter- in intrakomunikacijo znotraj mednarodne teroristične mreže, kar nevarno množi morebitne grožnje. Razvoj visokih tehnologij prehaja nacionalne meje, ki so vse poroznejše in ranljivejše, svet je vse manjši. Sproženje namernega izbruha bolezni, množične žrtve in splošna destrukcija so scenariji, ki dosegajo kritično raven oziroma se njihova magnituda nemoteno in eksponentno 
povečuje. Ni več vprašanje, ali lahko posameznik ali skupina ekstremistov uporabi biološko, kemično ali primitivno izdelano jedrsko orožje. Filozofija takšnega enkratnega uspešnega napada je preprosta, zgodili se bodo naslednji in množične žrtve so logično nadaljevanje. Orožje za množično uničevanje - JRKB/E - je že v novih, napačnih rokah, kar mednarodno skupnost oziroma mednarodni varnostni sistem postavlja $\mathrm{v}$ razmeroma nevarno območje. Biološko in kemično orožje sta »orožji prihodnosti« in bosta $\mathrm{v}$ kombinaciji z radiološkim in jedrskim orožjem najpogosteje uporabljeni na zgodnjih stopnjah konflikta, kar bi destabiliziralo varnostni sistem in logistično bazo ter povzročilo njun zlom.

Vsi napori, da se preprečijo pridobivanje, proizvodnja in kopičenje orožja za množično uničevanje, so odvisni predvsem od sposobnosti in pripravljenosti varnostnih sil. Vrhunsko opremljena varnostna sila že dolgo ni edini pogoj za uspeh v boju proti hitremu širjenju orožja za množično uničevanje oziroma v boju proti terorizmu. Ciljno izobraževanje in vzporedna osebnostna rast posameznikov v varnostnih silah ter večdimenzionalnost varnostne sile kot celote so eden izmed temeljnih pogojev, da grožnjo uporabe orožja za množično uničevanje ter sisteme za njegovo širitev obvladujemo oziroma preprečimo. Glavno sporočilo članka je namenjeno odpravi pomanjkanja razumevanja, da je posebno in za varnostne sile posebej prirejeno naravoslovno znanje na področju JRKB/E bistveno in bi moralo predstavljati ultimativno filozofijo zaščite varnostnih sil. Varnostne sile morajo najprej preživeti, da bi lahko zmagale, ščitile in zaščitile oziroma izpolnjevale ter izpolnile svoje temeljno poslanstvo.

Ključne besede

Abstract The international community is facing a third generation of terrorists. Global Salafi Jihad changed its course of action by following the "leader's design" without being specifically guided, informed or attached to the central strategic leadership. The Internet has become the terrorist's major tool of communication. The modification of the role and relationship to Islam and Islamic ideology, replaced the original Ibn Taymiya's philosophy of the 13th Century. The new generation of terrorists accustom their religious indoctrination from new age radical Islamic $t$ ideologists and from web sites and other media. The leading and unacceptably cruel web site's executive philosophy motivated the recording and broadcasting of decapitations along with unlimited excommunications, so called Tackfir, and causing the escalation of violence among Islamic "holy warriors" of the 21st Century. Kidnappings, hostage takings, ransom demands and extortion represent important sources of their "holy missions" financial backing. The new age terrorist's tactical concept and targeted areas of interest, in regards to counter terrorism have become a priority. Asymmetry is no longer the leading and sufficient term by which the new tactics and combat techniques of Jihad can be described or defined. The organized chaos regarding intraand intercommunication between the "holy warriors" and their strategic headquarter within the international terrorist network is multileveled and has varying degrees of 
possible threats. With advanced technologies and a smaller world with more open borders, the ability to unleash mass sickness, death, and destruction today has reached a greater magnitude. A lone madman or nest of fanatics with a bottle of chemicals, a batch of plague-inducing bacteria (virus), or a crude nuclear bomb, can threaten or kill tens of thousands of people with a single act. Weapons of mass destruction (WMD/CBRN/E- weapons) have already spread into new hands. These weapons pose a grave and urgent threat to international security. It is no longer questioned that use of biological and chemical weapons is a "likely condition of future warfare" and that these and nuclear weapons are likely to be used "early in the conflict to disrupt a security system and logistics".

Efforts to prevent certain groups from obtaining, manufacturing, or retaining these weapons crucially depend on the readiness of security forces. Well-equipped security forces are no longer enough. Education is crucial to triumph over an adversary who threatens or uses these weapons and their associated delivery systems. Therefore, the major message of the article is based on the extensive lack of understanding that a special and adjusted education system regarding WMD/CBRN/E- weapons should be the ultimate and is the only possible direction for security forces to ensure their survival, triumph, and ability to protect.

Key words CBRN/E-weapons, proliferation, security forces, education, terrorism. 